\title{
Application of Acoustic Emission (AE) in mining and earth sciences: a review
}

The Mining-Geology-Petroleum Engineering Bulletin UDC: 622.2:624.1

DOI: $10.17794 /$ rgn.2019.4.3

Review scientific paper

\author{
Mehrbod Khoshouei'; Raheb Bagherpour ${ }^{1}$ \\ ${ }^{1}$ Department of Mining Engineering, Isfahan University of Technology, Isfahan, 8415683111, Iran.
}

\begin{abstract}
One of the most important products of the majority of tools, processes and, phenomena in mining engineering and earth sciences are high-frequency elastic waves, often referred to as acoustic waves. These acoustic waves can be a useful tool for prediction and measurement, monitoring and diagnosis. Due to the importance of engineering activities that should be specific, measurable, available, reliable and time-based (SMART), Acoustic Emission (AE) techniques can be integrated into engineering operations such as excavation to give exact estimations or simplify some aspects of investigations. Hence, these techniques are expected to play an increasing role in the detection, monitoring, and measurement in engineering applications. With the development of acoustic signal processing methods in earth sciences and the growing need for accurate, fast, and cost-effective prediction, monitoring and measurement methods, AE tools and techniques are expected to turn into powerful alternatives to current methods. The purpose of this paper is to review the application of the acoustic methods as a tool in various projects. For this purpose, the application of AE methods has been reviewed in different fields related to earth sciences including mining engineering, drilling engineering, geology, petroleum engineering, and other related fields. According to the purpose of using these methods, the application of AE is divided into three groups: prediction and estimation, monitoring and performance assessment, and detection. The use of AE methods, among other laboratory or in-situ methods, is very fast and accurate, and by only installing specific sensors with data logging equipment, it has been able to process and analyse data online and remotely. Finally, the possibility of using AE techniques in design and calculating in various projects and as a tool for decision making was evaluated.
\end{abstract}

\section{Keywords}

Acoustic Emission; Signal processing techniques; Earth sciences and Mining engineering; SMART evaluations

\section{Introduction}

Geological and mining engineering tools and processes generate many products, some of which are intended and must be measured and others are by-products, such as vibration, heat and noise, which have little or no use for the intended purpose. Due to the importance of Acoustic Emission (AE) evaluations in engineering projects, especially in mining engineering that should be specific, measurable, available, reliable and time-based (SMART), these methods can be integrated into engineering operations to give exact estimations of material properties or to simplify some aspects of investigation such as support system monitoring in underground spaces. Recent years have seen growing attention to recording, processing and analysis of acoustic waves in a variety of applications, using simple and complex techniques. AE techniques are non-destructive methods with extensive applicability in the assessment of material behaviour and properties and equipment conditions (e.g. prediction of the rate of penetration or ROP), the selec-

Corresponding author: Raheb Bagherpour

bagherpour@cc.iut.ac.ir tion of the appropriate cutting and drilling tools and the monitoring of specific states or phenomena. This paper reviews the application of $\mathrm{AE}$ and the processing of acoustic signals generated during the operations and processes in mining engineering and geosciences.

$\mathrm{AE}$ can be generally defined as stress or pressure waves generated in materials by the energy released as a result of deformation or failure. The pressure waves, which propagate through the material at the speed of sound, can be detected by specific sensors and then analysed to gather information about the wave source and material (Liptai, Harris and Tatro, 1972).

AE signal processing is a powerful, fast and reliable method for assessing the operating conditions of mining machinery, for using in exploratory studies such as seismology, for controlling the mineral condition at different stages of processing (e.g. crushing, grinding, flotation, etc.), for monitoring the condition of machinery parts (e.g. engine, hydraulic jacks, wear-prone components such as buckets, blades, etc.), for predicting the physical and mechanical properties of rocks or building materials, for estimating the extent to which materials are fragmented and cutting tools (in dimensional stones cutting 


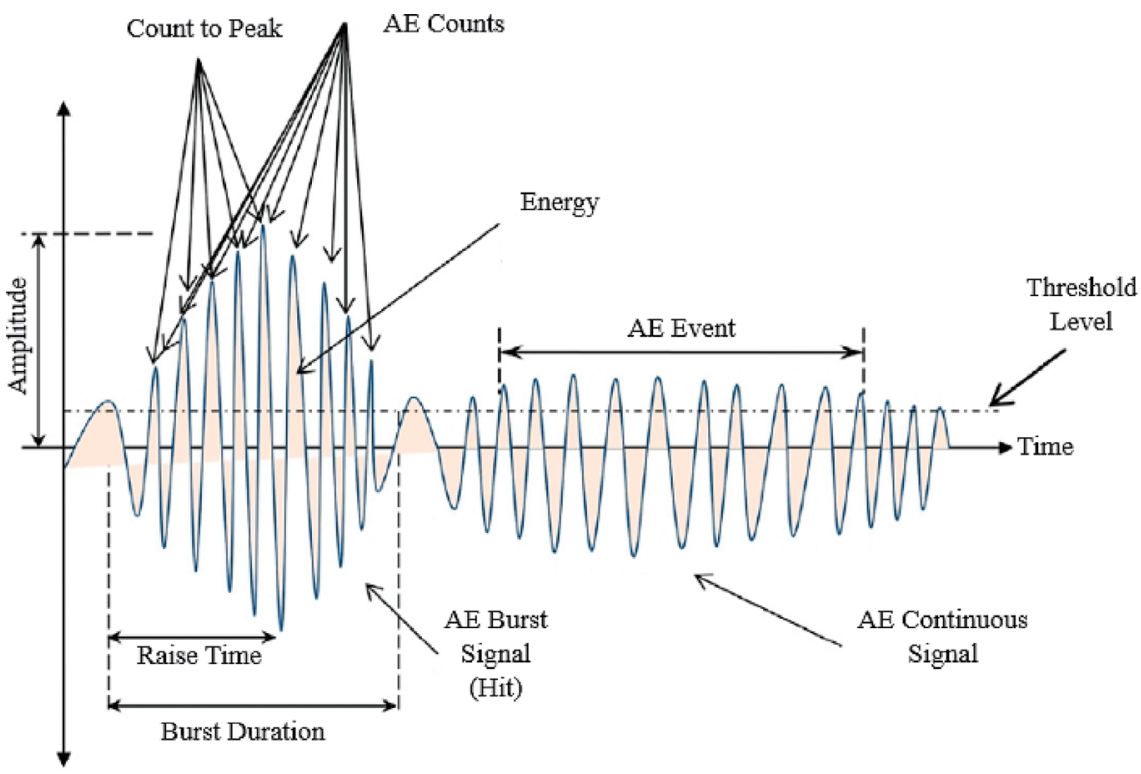

Figure 1: The typically AE signal features, adopted from:

(Ali, Hui, Hee and Leong, 2018)

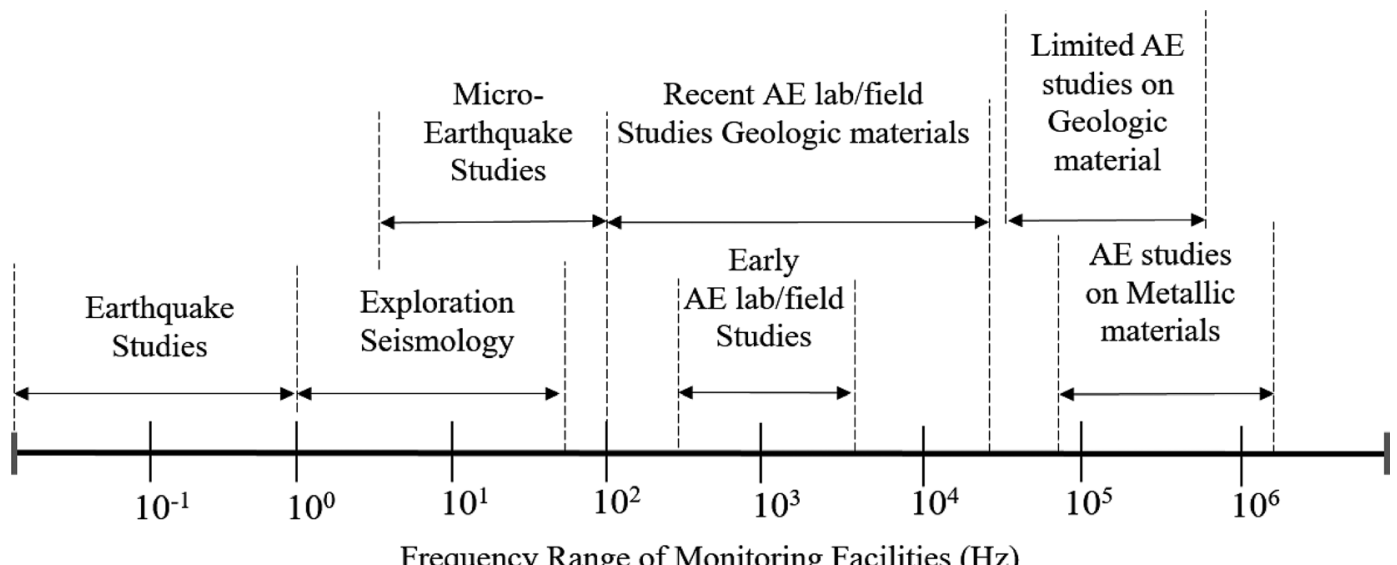

Figure 2: Frequency range of acoustic waves in different fields (Hopwood \& McGogney, 1987)

factories for example) are worn out, and for estimating solid phase content and specifications in multiphase flows.

Also, AE has extensive use in the detection and control of:

- Damage: including damage growth, crack and micro-crack propagation, plastic deformation, and surface damage such as corrosion.

- Reversible processes: including crystallographic phase changes, thawing/freezing, thermos-elastic effects, the motion of ferromagnetic domain structures and electric feeders, and friction between surfaces.

- Production processes: including the noise caused by welding, machining, drilling, mixing, cutting and crushing.

- Leaks and flows: including fluid flows, single-phase and two-phase flows, and gas leakage.
The above list provides a general overview of the applications of AE, but these applications are far more extensive (Scruby, 1987).

One of the challenges in the use of AE is how to extract the properties and features of AE signals produced in different processes. This requires a high level of signal processing and analysis of data collected from various sensors and measuring instruments (e.g. sound level meter), special microphones (e.g. focal microphones), and acoustic sensors.

Acoustic waves have different parameters and characteristics such as amplitude, wavelength, dominant frequency, phase, wave energy, intensity, and pressure, each of which can be used for a variety of purposes. Acoustic wave feature extraction is one of the most important and the most challenging steps of signal processing. The choice of signal processing method is also a determinant of how effectively the AE techniques can be 
Table 1: Summary of the literature review (common signal processing methods)

\begin{tabular}{|c|c|c|c|c|c|c|c|c|}
\hline Researcher Methods & FFT & Wavelet & HНT & $\begin{array}{l}\text { Spectrum } \\
\text { analysis }\end{array}$ & $\begin{array}{c}\text { Neural } \\
\text { network } \\
\text { models }\end{array}$ & CWD & $\begin{array}{c}\text { Acoustic } \\
\text { energy }\end{array}$ & $\begin{array}{c}\text { Sound } \\
\text { level }\end{array}$ \\
\hline (Qin et al., 2018) & & & & $x$ & & & & \\
\hline (Karakus \& Perez, 2014) & & & & $x$ & & & & \\
\hline (Kumar et al., 2013) & & & & & $x$ & & & $x$ \\
\hline (Bastari et al., 2011) & & $x$ & & & $x$ & & & \\
\hline (Parsian et al., 2017) & & & & $x$ & & & & \\
\hline (Marinescu \& Axinte, 2009) & $\times$ & & & $x$ & & $\times$ & & \\
\hline (Xiao, Hurich et al., 2018) & $x$ & & & & & & $x$ & \\
\hline (Li et al., 2018) & & & & $x$ & & & & \\
\hline (Buj-Corral et al.,, 2018) & $x$ & & $x$ & & & & & \\
\hline (Shaffer et al.,, 2018) & & & & $x$ & & & & \\
\hline (Wang et al., 2017) & $x$ & & & $x$ & & & $x$ & \\
\hline (Rivero et al., 2008) & $\times$ & $\times$ & & & & & & \\
\hline (Flegner et al., 2014) & $x$ & & & & & & & \\
\hline (Feng \& Yi, 2017) & & & $x$ & & & & & \\
\hline (Yari et al., 2017) & $x$ & & & & & & & \\
\hline (Yari \& Bagherpour, 2018 (a\&b)) & $x$ & & & & & & & \\
\hline (Shreedharan et al., 2014) & $x$ & & & & & & & \\
\hline (Kostur \& Futo, 2007) & & & & $x$ & & & & \\
\hline (Kawamura et al., 2017) & & $x$ & & & & & & \\
\hline (Pedrayes et al., 2018) & & & & $x$ & & & & \\
\hline (Gradl et al., 2012) & $x$ & & & $x$ & & & & \\
\hline (Kumar et al., 2013) & & & & & $x$ & & & $x$ \\
\hline (Vardhan et al., 2009) & & & & & & & & $x$ \\
\hline (Beheshtizadeh et al., 2017) & $x$ & $x$ & & & & $x$ & & \\
\hline (Miklusova et al., 2006) & $x$ & & & & & & & \\
\hline (Goyal \& Pabla, 2016) & $x$ & $x$ & $x$ & $x$ & & & & \\
\hline (Liew \& Wang, 1998) & & $x$ & & & & & & \\
\hline (Zhu et al., 2016) & & & $x$ & & & & & \\
\hline (Kong et al., 2015) & & & & $x$ & & & & \\
\hline (Jain et al., 2001) & $x$ & & & & & & & \\
\hline
\end{tabular}

used. One efficient way to extract information from the acoustic waves generated from a source is to use featurebased methods. The proper choice, detection and use of acoustic wave features are among the most important steps in AE signal processing. Some features typically extracted from simple acoustic waves are shown in Figure 1.

The AE spectrum are usually in a wide range of frequencies. Normally, the AE spectrum, near the source, contains higher frequencies than at farther distances; a phenomenon that must be attributed to the propagation of acoustic waves through the material. In a study carried out by Zborovjan, it was reported that the frequency of acoustic waves generated during rock and mineral excavation ranges between $5000 \mathrm{~Hz}$ and $8000 \mathrm{~Hz}$, which matches the frequency range illustrated in Figure 2
(Zborovjan, 2002; Zborovjan, Lesso and Dorcak, 2003). In this figure, the approximate frequency range of frequencies is shown in various processes related to earth sciences.

\section{Acoustic Signal Processing, Feature Extraction and pattern recognition Methods}

To extract information from an AE signal, one has to use a signal processing, feature extraction, or pattern recognition technique developed for these signals (Caesarendra et al., 2016). Accordingly, the AE signal processing methods can be classified into three categories: (i) signal processing, (ii) feature extraction, and (iii) pattern recognition. The most important and widely used 
methods of the first category (signal processing) include: time series statistical models, Short Time Fourier Transform (STFT), Fast Fourier Transform (FFT), Wavelet Packet Decomposition (WPD), Hilbert-Huang transform (HHT), Wigner-Ville distribution, signal spectrum analysis, Adaptive Line Enhancer (ALE), wavelet transform, and the Peak-Hold-Down-Sample (PHDS) algorithm. Notable methods of the second category (feature extraction) and the features used by these methods include: the Energy Index (EI) technique, approximate entropy, spectrum analysis, Peak ratio (PR), Zero-inflated Poisson (ZIP), AE mean and standard deviation ratios, Power Spectral Density (PSD), complex Morlet wavelet, Auto-Regression (AR), short-term energy function, and the High Frequency Resonant Technique (HFRT). Among the methods of the third category (pattern recognition and clustering), Fuzzy c-mean clustering, Relevance Vector Machine (RVM), Support Vector Machine (SVM), Multi-class RVM, k-means clustering, Cohen's Class, Asymmetric Proximity Function with K-Nearest

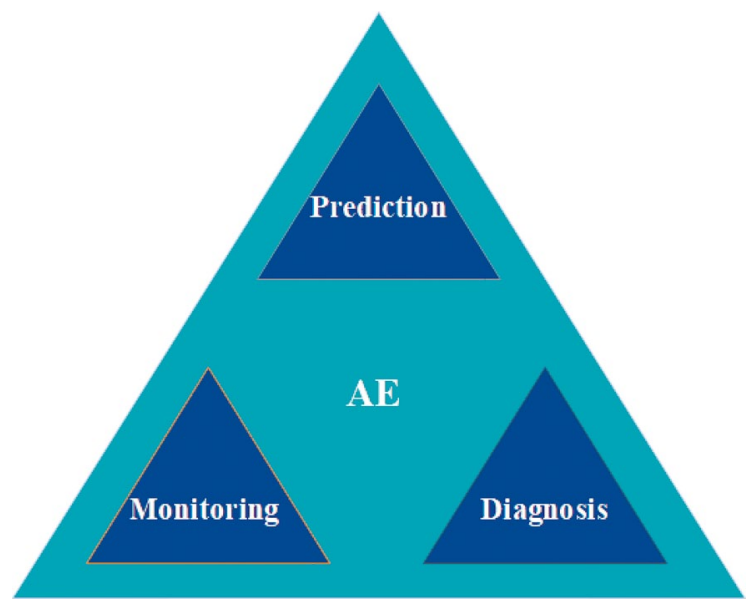

Figure 3: Three main groups of AE application
Neighbour (APF-KNN), and genetic algorithm are the most widely used. Since the 1950 s, AE has been a subject of great interest to many researchers. In this paper, some of the more significant studies that have either introduced an AE signal processing technique or applied a signal processing technique in mining studies are reviewed. A list of studies reviewed in this paper is presented in Table 1.

Acoustic wave processing methods are recognised and popular for their high speed, accuracy and their reliability. AE methods can integrate into many processes and equipment such as excavation machinery, mineral processing equipment and rock mechanics testing devices.

This paper consists of two main sections; the first section contains the introduction of conventional signal processing techniques. These methods can be divided into three groups: signal processing, feature extraction and pattern recognition. The second section is a review of various studies in the field of earth sciences. Generally, as shown in Figure 3, the application of AE can be divided into three groups of prediction or estimation, monitoring and diagnosis. Studies on AE in mining and earth sciences were also categorized and reviewed in the same three groups.

\section{Application of AE in mining engineering and earth sciences}

In this section, the studies conducted in the past 70 years on the application of $\mathrm{AE}$ techniques in mining engineering and also related sciences such as geology and geotechnics, civil engineering, materials engineering and metallurgy are reviewed. For example, the application of $\mathrm{AE}$ in a drilling process is shown in Figure 4. As shown in Figure 3, the past studies on the use of AE in

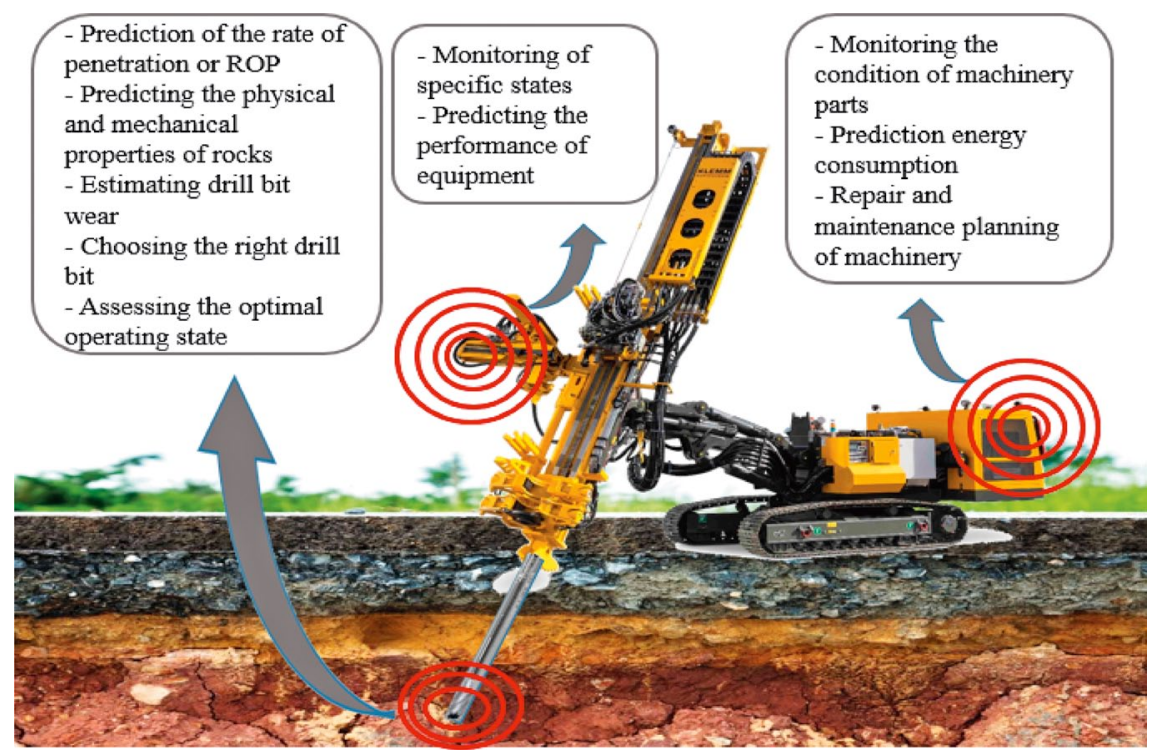

Figure 4: Application of AE in drilling process 
earth sciences can be classified into three categories based on their application. These applications are reviewed in the following subsections.

\subsection{Use of AE for prediction}

The prediction of physical and mechanical properties of rocks is among the most important processes in mining engineering fields such as exploration, excavation, rock structure design, and mineral processing. These predictions are also of immense importance for estimating drill bit wear (Rivero et al., 2008), predicting the ROP (Krúpa et al., 2018), choosing the right blasting materials and method for each particular rock, determining the proper feed rate for mineral processing equipment, and predicting the performance of equipment.

The earliest important study on the use of AE in mining was the study conducted by Obert and Duvall in 1941, where the acoustic signal was used for rock burst prediction in mines. In this study, acoustic tests were performed on the rocks inside silver, lead and zinc mines of western U.S., which were being extracted by the cut and fill method. The micro seismicity data of 101 bursts were collected by an apparatus including a geophone, an amplifier and a rock burst measuring device (RBM) over a period of 1097 days. The statistical analyses were carried out to determine the relationships between rock burst and blasting, between the magnitude of rock burst and the resulting damage, and between the seismicity of rock burst and the mine geometry as well as the incidence of medium-scale rock bursts. The results of the statistical analyses showed that $91 \%$ of rock burst were directly caused by blasting activities and only $3 \%$ were independent of blasts. The results of this research showed explicitly and quantitatively what was known about rock bursts by experience. These researchers recommended further research into the close relationship between rock bursts and blasting and on burst sequences (Obert \& Duvall, 1941). In 1968, Knill et al. conducted research on laboratory systems that can be used for detection, recording, and analysis of acoustic waves, interpretation of recorded signals, and practical use of acoustic techniques in rock mechanics. For this purpose, an experimental acoustic system was designed in a laboratory and was mounted on a rock loading machine. Various acoustic parameters such as pulse rate, signal energy content and amplitude distribution were defined, and the changes in these parameters during uniaxial loading of rock samples were determined. This study reported that, like geophysical methods, the AE technique suffers from several weaknesses that make it susceptible to interpretation error and suggested that it cannot be used as the sole basis of analysis. However, it was also concluded that this technique would be a powerful tool for analysing the behaviour of materials and would find extensive use in many applications (Knill, Franklin and Malone, 1968). In 1974, Szlavin examined whether there is a statistically significant correlation between the mechanical properties of rocks so that one property can be estimated based on another. In this research, a program was designed for computing the inter-variable relationships (namely regression, standard deviation, and correlation) of the experimental results fed into a computer. The results of this study showed that most of the main mechanical properties, such as strength and hardness, can be accurately estimated based on other properties, but there would be significant errors in the estimation of energybased indices such as specific energy and wear (Szlavin, 1974). In 1990, McNally introduced an exponential relationship between uniaxial compressive strength (USC) and sonic logs based on the results of UCS tests performed on thousands of core samples and geophysical logs obtained from the Bowen Basin. This relationship became a widely accepted method in Australian coal mining community for estimating UCS from sonic logs. The McNally method can be considered the first method for the practical estimation of rock strength based on sonic logs (McNally, 1990). In 1993, Wervaal and Mulder studied a series of rock samples in order to predict their UCS based on the L value of Equotip hammer. They presented a diagram illustrating the relationship between UCS and L value and discussed the effect of surface roughness on Equotip measurements (Verwaal \& Mulder, 1993). In 1994, Jung et al. predicted the rock hardness and drillability based on AE signatures. The experiments of this study were performed on gneiss, granite, quartzite, dacite, sandstone, mudstone, and argillite, and ultimately the load-displacement, AE root mean square (RMS)-time, AE number-time, and $\mathrm{AE}$ signal-time relationships were analysed. The rock penetration experiments revealed a clear relationship between the rock hardness and the acoustic signatures studied in that work. Among the studied parameters, RMS was found to have the highest correlation with rock hardness. However, it was also concluded that to reach comparable results, the tests should be carried out under well-defined identical conditions (Jung, Prisbrey and $\mathrm{Wu}, 1994)$. Following the introduction of the McNally method, a method was needed to incorporate local specifications into the estimation of UCS based on sonic logs. For this purpose, in 1998, Ward proposed some formulations for strong and weak layers in German and Greek mines (Ward, 1998). Recently, studies on the application of AE entered a new era. These studies were particularly focused on the noise generated while drilling, as they were searching for a logical relationship between these noises and the physical and mechanical properties of the rock being excavated. Notable among these works is research carried out by Kawasaki et al. (2002), where Equotip hardness tests, compaction tests, and elastic wave measurements were performed on core samples taken from sandstone, shale, greenschist, hornfels and granite rocks from several regions in Japan (Kawasaki, Tanimoto, Koizumi and Ishikawa, 2002). Hatherly (2002) proposed an alternative method for estimating the UCS of elastic rocks based on geophysical 
borehole logs. Arguing that rock composition is a major determinant of rock strength, this research first quantified the composition of the studied rocks and then investigated the correlation of this composition with UCS (Hatherly, 2002). Rivero et al. (2008) used signal processing to estimate the wear of components in dry highspeed milling. This work was focused on without sensor monitoring of wear in the milling tools commonly used in the processing of aluminium alloys based on the machine's internal signals. This study showed that the machine's internal signals can give an estimate of the tool wear. In this work, acoustic signal processing was performed using Fourier transform and wavelet transform methods (Rivero et al., 2008). In 2009, Vardhan et al. investigated the effect of sound level on the estimation of rock mass properties, such as compressive strength. This investigation was performed using a jackhammer drill fabricated on a laboratory scale which allowed the researchers to apply varying thrust forces while drilling vertical holes. This study showed that it is indeed possible to estimate rock strength based on the sound level generated in the drilling process, as the generated sound level varies with rock properties. This study reported that, in general, the higher the rock strength, the higher the sound level, but the sound level is also related to the weight on the bit (Vardhan et al., 2009). In 2010, Kumar et al. studied the use of sound level properties in the prediction of physical and mechanical properties on the field scale (Kumar, Vardhan and Govindaraj, 2010). Furthermore, they used the regression method to predict the physical and mechanical properties of metamorphic rocks. In this study, researchers tried to find a logical mathematical relationship between physical and mechanical properties of different rocks and the bit diameter, ROP, bit rotation speed, and equivalent sound pressure level $\left(L_{\mathrm{eq}}\right)$ (Kumar, Vardhan and Govindaraj, 2011a). In 2011, they used multivariate regression to relate the UCS, tensile strength (TS), and porosity of sedimentary rocks to $L_{\text {eq }}$, bit diameter, bit rotation speed, and ROP. This study showed that this regression could serve as a quick and easy technique for the estimation of UCS, TS, and porosity in sedimentary rocks, and suggested that future studies should follow similar approaches (Kumar, Vardhan and Govindaraj, 2011b). In 2011, Bastari et al. used the acoustic signal processing techniques to analyse the signal spectrum for measuring powder particles. This study introduced a novel method for measuring particle size based on the application of signal processing techniques. The main idea of this work was to formulate the unknown relationships between the acoustic signal spectrum and the particle size distribution using a multistage method consisting of a wavelet packet decomposition stage for extracting the useful signal features, and an artificial neural network stage for estimating particle size distribution. The researchers claimed that in addition to being low cost and having low hardware complexity, this method can operate online without the supervision of experienced operators. It was also stated that additional data related to the general state of the software operating system can be introduced to multivariate data analysis in a stepwise manner (Bastari et al., 2011). In 2011, Kumar et al. conducted a case study on the relationship of sound level with the mechanical properties of sedimentary and igneous rocks. The aim of this study was to develop a comprehensive prediction model and to investigate the relationship between the sound level generated during drilling and physical properties such as USC and TS and porosity. The variables selected for this multivariate regression model were the bit diameter, bit rotation speed, ROP, and the equivalent sound level generated during rotary drilling (Kumar et al., 2011a). In 2012, Gradl et al. measured the noise generated by drilling with a microphone and a geophone and used the measurements to analyse the relationship between the bit design and its seismic and acoustic properties. Using frequency analysis, they showed that each bit generates unique sounds and vibrational effects and that the sound generated during drilling can be correlated with vibration. The results of this research contributed to the real-time identification of bit problems using the sound data collected by a microphone (Gradl et al., 2012).

In 2013, Kumar et al. used UCS, air pressure and thrust force applied on the bit to predict the sound level and ROP of the drilling machine with an artificial neural network (Kumar, Vardhan, Govindaraj and Saraswathi, 2013). In this year, Vardhan et al. further expanded their previous works on the equivalent sound level of drilling. In this study, rock properties were predicted using simple computational methods such as multivariate regression and artificial neural networks (MLP and RBF) with bit diameter and rotation speed, ROP, and the equivalent sound level used as input. This study found that regression and neural network techniques yield similar results and that neural networks are generally well capable of predicting rock properties based on sound level. This study suggested that the effect of rock joints on the level of drilling noise requires further investigation and that artificial joints created by cutting can be used for this purpose (Kumar, Vardhan, Govindaraj and Vijay, 2013). In 2014, Karakus et al. analysed the spectrum of audio signals resulting from the bit-rock collision during core drilling. In this work, acoustic sensors were used to record the audio signals produced during drilling with a laboratory-scale core drill. The test results provided several linear relationships for estimating the cutting depth, Weight on Bit (WOB), and Torque on Bit (TOB) based on the time spectrum of acoustic signals. This method allows easier control over drilling conditions with the signal spectrum analysis. This study showed that AE monitoring techniques are a viable option for optimizing the performance of core drills with diamond bits and can provide accurate indicators for tracking changes in drilling conditions and the effect of drilling parameters (Karakus \& Perez, 2014). In another study published in 2014, Flegner et al. measured 
and analysed the acoustic signals generated during rotary drilling. In the time domain, the most important results were obtained from the histogram of signals associated with single rock layers and the drilling method. In the frequency domain, the spectrum of acoustic signals was used to analyse the dynamic properties of the drilling process. Overall, this research aimed to lay the groundwork for the development of more advanced acoustic signal processing methods in the future (Flegner et al., 2014). In 2015, Schon reported that there is a logarithmic, polynomial, or linear relationship between seismic velocity and UCS. This conclusion was made based on the noises generated from sources such as drill bit-rock contact, drill engine, and cooler fluid during the rotary drilling process (Schön, 2015). Voznesenski et al. studied the relationship of compressive strength, Young's modulus, and other properties of halite (rock salt) with the acoustic quality factor. In this study, the halite sample was subjected to periodic loading and the minimum compressive strength and Young's modulus were observed after 20 cycles. The results of this study suggested that the acoustic quality factor can be used to estimate the deformation and strength of halite samples, which is important for exploiting underground gas deposits in salt caverns and for rock salt mining (Voznesenskii, Krasilov, Kutkin, Tavostin and Osipov, 2017).

Yari et al. (2017 and 2018) conducted a series of studies on the application of acoustic signal processing in rotary drilling so as to determine whether a relationship can be found between the dominant frequencies of audio signals generated during drilling and the physical and mechanical properties of igneous, metamorphic, sedimentary and carbonate rocks. After performing the drilling tests, they analysed the obtained sound signals to estimate UCS, TS, P-wave velocity, and porosity. These studies demonstrated the existence of an acceptably consistent relationship between rock properties and the dominant frequencies of sound signals (Yari \& Bagherpour, 2018; Yari et al., 2017). In a study by Krúpa et al., they measured, modelled, and predicted the depth of penetration in rotary drilling. They used the available data on the depth of penetration and other parameters to predict the bit wear, arguing that since continuous bit wear during rotary drilling decreases drilling performance and it is impossible to directly measure wear, it is essential to use such indirect methods for this purpose (Krúpa et al., 2018). One of the newest applications of acoustic signal processing is the function and performance monitoring of mills. For example, Pedrayes et al. (2018) have used signal processing to predict torque in tumbling ball mills. This study shows that the signal analysis in the frequency domain can provide a good assessment of load torque in these mills. According to this study, the load torque signal in ball mills is empirically related to the load level of the mill. This study observed that for tumbling ball mills, there are always some harmonics associated with the rotation speed and the number of lifters, which was called lifter torque harmonic
(LTH). Ultimately it was demonstrated that the load level of these mills can be estimated based on torque conditions (Pedrayes et al., 2018). Another application of AE techniques in mills is the prediction of particle size distribution and the assessment of processes such as crushing and flotation (Aldrich, 2000; Mohanty, Gupta and Raju, 2015; Spencer et al., 2010).

\subsection{Use of AE for assessment and monitoring}

In many operations, it is of virtual importance to control how machines and equipment behave to collect and maintain useful data for better problem diagnosis and decision making. This assessment and monitoring typically involves continuous or periodic inspection of the conditions, which allows for more effective implementation of maintenance operations and other measures that improve the system safety and reliability (Khoshouei et al., 2018). Sometimes, it is more affordable to commit to continuous or real-time equipment assessment than to suffer downtime or equipment wear. The various techniques available for monitoring are shown in Figure 5.

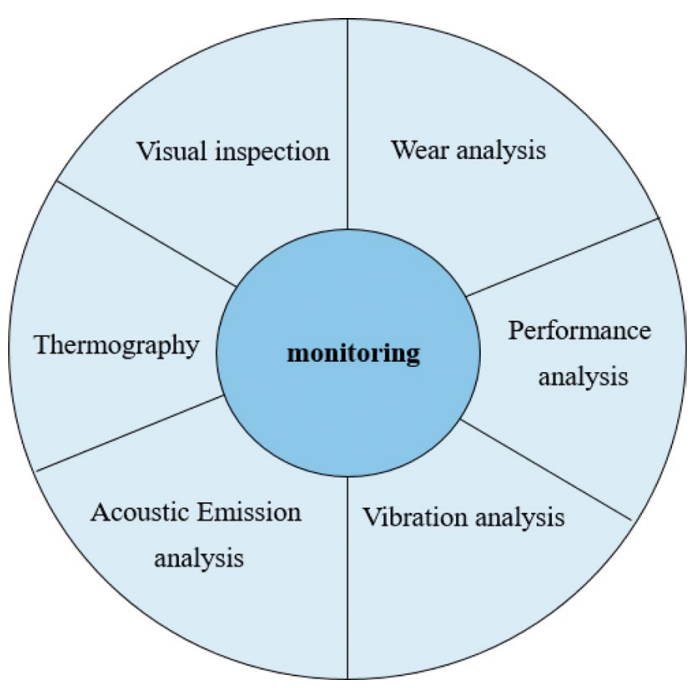

Figure 5: Various techniques for monitoring

In this section, the applications of $\mathrm{AE}$ analysis methods in monitoring and behaviour assessment are reviewed. In the 1980s and 1990s, variations in the amplitude of the acoustic wave spectrum in different frequency bands and their relations with stresses were studied by several researchers including Hardy (1972), Marceau \& Moji (1973), Byerlee (1978), and Knill et al. (1968). At the same time, several works were published on the applications of AE in different materials in laboratory and non-laboratory settings (Byerlee, 1978; Hardy, 1972; Knill et al., 1968; Marceau \& Moji, 1973). In 1977, Raffenetti investigated the use of sonic tools in the identification of formations under pressure during drilling (Raffenetti, Hsu and Shavitt, 1977). In 2003, Futo and Ivaničová studied the possibility of optimizing 
the drilling operation based on acoustic signals. In this study, the rock disintegration process, the thrust applied on the drill bit, drilling speed, and the disintegration power were analysed. These researchers also designed a system for sound monitoring during the disintegration process. Ultimately, this study concluded that the equivalent sound level for the representative frequency depends on the rock type and can, therefore, be used to identify the type of rock being drilled (Futó \& Ivaničová, 2003). In another study, Zborovjan et al. investigated the acoustic effects of rocks in drilling operations and found that the acoustic signal obtained during rotary drilling can be used to control the drilling process. The software provided in this study managed to produce satisfactory results in terms of rock classification (Zborovjan et al., 2003). Miklusova et al. (2006) presented a laboratory machine for the simulation of rock disintegration during rotary drilling. This machine provides rock samples subjected to rotary drilling with small diameter drilling tools. The results of this study showed that, when properly analysed with the fast Fourier transform (FFT), the acoustic signal obtained during rotary drilling can be used to control the drilling process (Miklusova et al., 2006). Research by Leššo et al. (2007), which analysed the acoustic signals collected from drilling experiments as an integrated data source, proved that the acoustic signal emitted during the drilling process strongly depends on the physical and mechanical properties of rock samples (Leššo, Flegner, Pandula and Horovčák, 2007). In 2009, Marinescu et al. carried out a study aimed at using time-frequency spectrum analysis to evaluate the behaviour and performance of bits. This work was the first to show that the surface condition and malfunction of cutting bits can be assessed by the timefrequency spectrum (T-F) of sonic signals (Marinescu \& Axinte, 2009).

In 2010, Spencer et al. investigated the use of AE in the monitoring and assessment of flotation cells. Investigations of this study were performed on two laboratory flotation cells (Agitair A40 and Denver D-12). The generated acoustic signals were recorded by hydrophones installed at different positions within the cells and accelerometers on their outer walls. The changes in the acoustic spectrum after changing the test conditions such as air intake, froth maker settings, and rotation speed were observed and recorded. The results showed the robust performance of sensors in the assessment of floatation (Spencer et al., 2010). In 2017, Parsian et al. attempted to control and assess the drilling process through a time-frequency analysis of sonic signals generated while drilling. In this work, the sound level, sound pressure, and RMS level were used to achieve this goal. This study also discussed common expectations from sound measurements in drilling operations and various dynamic phenomena (Parsian et al., 2017).

$\mathrm{AE}$ has also found extensive application in concrete construction and monitoring operations. In a study by
Archana Nair and Cai. (2010), they reviewed the applications of AE techniques in the structural health monitoring of bridges. In this research, statistical and analytical methods were studied through two case studies, a steel bridge and a concrete bridge, based on three common materials, namely concrete, steel, and FRP. The result analysis of acoustic data showed that, given the technological improvement in this field, this method can significantly contribute to inspection. This study demonstrated that the results are more reliable when the structure has a limited envelope, shell or covering (Nair \& Cai, 2010). The recent years have seen a growing use of $\mathrm{AE}$ techniques in the assessment of concrete. This is partly because the complexity of reinforced concrete members makes it very difficult to evaluate their damage and their mechanical properties through non-destructive methods. This explains the increasing use of AE techniques in concrete damage detection. For example, Aggelis et al. (2009) examined the failure behaviour of various cement samples using AE and Ultrasonic Transmission (UT) techniques. this study showed that $\mathrm{AE}$ and UT can very well determine the time and place of cracking and provide a good assessment of damage and deterioration conditions (Aggelis, Shiotani, Momoki and Hirama, 2009). A study by Feng and Yi. (2017), which examined the propagation characteristics of acoustic waves in concrete, reported that the characteristics of AE in concrete structures can be assessed quantitatively by the use of the Hilbert-Huang transform (HHT) (Feng \& Yi, 2017). Buj-Corral et al. used the FFT and HHT method for analysis of signals obtained from a cutting machine. After extracting the frequency-based acoustic characteristics, the AE method was used for real-time assessment of the cutting machine. The results of this study suggest that the optimal cutting condition can be achieved by the signal characteristics (Buj-Corral et al., 2018).

Another application of AE is the direct measurement of the solid phase in two-phase water-sand flows in industrial processes, which is especially important for oil extraction from aging oil fields. In this regard, Wang et al. developed a method for overcoming the limitations in the measurement of the solid phase in liquid and solidliquid conveying systems, and specifically for the use of special sonic sensors to detect sand phase in such flows. In this study, the tests were performed on a sand-water flow with sand content of $0.00294 \%$ vol. to $0.204 \%$ vol. with a particle size of 180 micrometers to 500 micrometers. The quantitative analysis of sonic signals showed that the sand mass flow rate correlated well with the acoustic power spectrum (less than $\pm 15 \%$ error in bends and less than $\pm 10 \%$ error in impact regions). This article provided an alternative method for detecting sand particles in dilute solid-liquid conveying systems, which can be considered a good basis for future works (Wang et al., 2017). Another application of acoustic signal processing is in the evaluation of vibration drilling. In a 
study by, Xiao (2018) et al. for example, they found a good correlation between these vibrations and the energy of AE signals. The drill bit penetration mechanism was found to be indirectly related to the peak frequency and spectral centroid and average energy and correlated well with the cutting size. This study reported the following results:

1. With an increase in WOB and also in vibration level, the ROP showed a positive correlation with $\mathrm{AE}$ energy, crack size, particle size distribution and mean particle size.

2. The diamond bit penetration mechanism was indirectly characterized by peak frequency, spectral centroid and average energy, which also correlated well with crack size.

3. Higher vibration levels were found to improve the diamond bit-rock interaction, thus contributing to drilling performance (Xiao et al., 2018).

\subsection{Use of AE for diagnosis}

One of the shared challenges of almost all engineering fields is how to find a low cost, accurate and reliable method for the fast investigation of states, functions, or instruments. AE techniques can be used as powerful tools for assessing the optimal operating state, speed, and energy consumption of a process and determining whether it is being carried out by the correct tools (Filipussi, Guzmán, Xargay, Hucailuk and Torres, 2015). In this subsection, some of the studies in this area are reviewed. In 1989, several experiments were conducted on electromagnetic and $\mathrm{AE}$ in rocks to understand the physical mechanism of electromagnetic emission before earthquakes. The results showed that tensile cracks have a stronger impact on the generation of acoustic waves than shear cracks. So, the creation of tensile cracks and the recording of acoustic signals may provide some insight into the occurrence of earthquakes. The results reported in this study can be summarized as follows:

- The emission of electromagnetic waves is associated with the growth of micro-cracks.

- The amplitude of the electromagnetic spectrum depends on the components with frequencies of more than $500 \mathrm{kHz}$, although, the frequency size depends on the micro-crack growth or size.

- Tensile cracks have more impact on the generation of electromagnetic waves than shear cracks.

- High-frequency acoustic waves have a stronger effect on the generation of electromagnetic waves than low-frequency ones (Yamada, Masuda and Mizutani, 1989).

Micro-crack detection is very important for the study of characteristics of hydrocarbon and geothermal reservoirs. As a result, acoustic wave processing and analysis is one of the methods that can enhance our understanding of damage mechanisms in hydrocarbon reservoirs (Hampton, Gutierrez, Matzar, Hu and Frash, 2018).
In 1991, Boness et al. used acoustic waves for the examination of abrasive properties. The results of this study showed that the time-dependent components of acoustic signals can be used to detect the effect of wearreducing additives (Boness \& McBride, 1991). Another notable work in this area is research published in 2005 on the analysis of sonic signals from the drilling process. In this study, the sound in drilling was attributed to all the components involved in the drilling process, including drilling equipment, the drill bit and the rock itself. After recording the signals, the dependencies between the input values and the signal characteristics were illustrated (Futó, Kostúr and Kačur, 2005). Zborovjan et al. also studied the acoustic signal based identification of rocks during the drilling process (Zborovjan et al., 2003). They argued that since rock drilling is a high-energy operation, the drilling rate must be optimized in order to decrease energy consumption. They added that knowing the rock type is important for this optimization as it determines the ROP that is most suitable for minimizing energy consumption. As mentioned, one way to determine the type of rock being drilled is to analyse the sound generated during the drilling operation. Hence, this study attempted to identify the specific acoustic effects that can be linked to a specific type of rock or at least help rock classification.

In 2006, Williams and Hagan investigated how the acoustic signal type generated in the rock changes with the rock cutting conditions. In this study, they observed changes in the signal nature depending on the use of worn or new indentations, the depth of cutting, and the damping of the acoustic signal with distance. It was also found that any change in cutting conditions had measurable effects on AE properties (Williams \& Hagan, 2006). In 2007, Vardhan and Murthy conducted a laboratory research where they examined the acoustic effects of drilling with a jackhammer drill in rocks with different properties. This research concluded that sound level variations depend on several properties including UCS and abrasion resistance of the rock (Vardhan \& Murthy, 2007).

In 2013, Karakurt et al. conducted an empirical and statistical analysis on the noise level generated during rock cutting with diamond saw blades. In this research, the effect of operating variables and rock properties on the noise properties was investigated. Nine granite rock samples with different mineral contents and particle size distributions from Turkey and other countries were used in this study. This study found that higher speeds and cutting depths correspond to higher noise levels. Also, the noise level decreased with an increase in the cooling fluid flow rate. A moderate correlation was also reported between UCS, density and noise level. Overall, the study claimed that the proposed analytical models may serve as roadmaps for practical applications (Karakurt, Aydin and Aydiner, 2013). In 2017, Kawamura used noise data to determine when the button bits of hard rock drills are going to break. This study argued that since the 
failure of these button bits imposes a financial loss and are difficult to estimate empirically, there is a need for a way to accurately determine this moment. In this study, this goal was achieved by analysing the noise data. This analysis was performed using time series analysis, FFT, and wavelet transform. The experimental results showed that the wavelet transform provides better estimates of the button bit breaking moment than FFT. Ultimately, researchers suggested that the noise generated during drilling operations can be used for the assessment of the drill bit condition (Kawamura et al., 2017).

Another area where AE techniques are useful is in oil exploration and exploitation, and more specifically in petrologic studies, which are of vital importance for the success of oil drilling operations. Qin investigated the relationship between rock properties and the properties of acoustic signals generated during drilling. For this purpose, they constructed a rock drilling vibration test system and used it to perform drilling tests. This study found that vibration and acoustic sensors can be used to identify the characteristics that can be related to the type of rock being drilled. It also demonstrated that the acoustic signals collected from drilling in four different types of rock had significantly different spectral characteristics and stated that this could be a promising discovery for petrologic investigations (Qin et al., 2018). Another application of AE technique is in coal mining, and specifically the analysis of methane trapped in coal layers (Du et al., 2018; Kong et al., 2015; Utley, 1980). AE techniques can also be used in the assessment of fragile rocks, especially coal, and how they get fragmented under cyclic loading. In a study by Li et al. (2018), they examined the acoustic properties of fragmenting materials. They proposed a new method for analysing AE signals during loading with an AE control system. This study reported a correlation between the fragmentation ratio and the changes of acoustic signal pattern, suggesting that these signals can be used for accurate estimation of material conditions. Also, a relationship was recognised between AE signals and grain fragmentation. Thus, a practical method was provided to study the properties of grain fragmentation under loading (Lavrov, Wevers and Vervoort, 2002; Li et al., 2018).

Another application of AE technique is the detection of rock slides. For example, Xing Zhu et al. investigated the low-frequency acoustic signals of rock falls as well as other phenomena such as landslides, thunderstorms, and winds. For this investigation, recording equipment was deployed on site to record low-frequency acoustic signals of rock falls and the resulting signals were analysed using the joint time-frequency distribution spectra method. The analysis results showed the ability of Empirical Mode Decomposition (EMD) based signal processing method to extract distinctive features for differentiating acoustic signals in real environments (Zhu et al., 2016). Finding a low-cost method with high accuracy and speed for detecting a particular phenome- non, such as rock type, or the type of rock failure in the rock slopes, or the characteristics of materials to select the right tool for extraction is very important. Based on studies in the AE application for detecting, it has been observed that changes in each parameter, including the operating parameters or properties of the materials studied, creates changes in the acoustic waves produced. By processing or extracting the signal profile, a diagnosis can be made accurately and quickly. Using this method, there is less need for measurement equipment, which is sometimes expensive and inappropriate in some places, such as tunnels or blasting sites.

\section{Conclusion}

The use of AE techniques has seen growth in many engineering fields including geotechnics, mining engineering, and many other fields related to earth sciences, due to the complexity and cost of many of the processes used in these projects. It is very important to find a method that can be accurate, inexpensive and fast for various operations in projects such as design, estimating and other evaluations. There are several techniques and processes for optimal evaluation, one of these methods is AE techniques. The purpose of this review is to investigate the applicability of AE in fields of earth sciences for the prediction of physical and mechanical properties of materials, fragmentation of materials in mineral processing, wear of cutting and drilling tools, and energy consumption of processes and the performance assessment of machinery or equipment, in the diagnosis of tools and processes, in petrologic studies (like oil exploration), in the determination of particle type and size in multiphase flows, in damage detection in concrete, shotcrete and concrete structures in general, and in the repair and maintenance planning of mining machinery based on failure predictions.

Given that the majority of existing works on the applications of AE can be described as laboratory research, more on-site experiments are needed to expand the industrial applications of AE techniques. It was concluded from this review of research literature, that AE techniques concerned in the following advantages over other alternative methods:

- AE techniques are dynamic detection methods that allow for the immediate detection of changes in signals.

- Using these techniques, samples can be studied from a distance.

- They can be utilized without stopping in the main operation.

- These methods have a low cost-to-performance ratio.

- AE techniques can be developed to get extremely high sensitivity and accuracy.

- These techniques are non-destructive methods.

- They are extremely fast and, in some cases, can be utilized in real time measuring. 
According to this review on the applications of $\mathrm{AE}$ techniques in mining operations such as rock drilling, these applications involve a wide variety of acoustic signal processing methods, each suitable for extracting different features from a time or frequency domain spectrum on track correlations between signal characteristics and physical and mechanical properties or monitoring the performance of tools or equipment. As mentioned, further developments in the processing of acoustic signals can greatly contribute to the progress of AE techniques in mining, geological and geotechnical operations such as prospecting and exploration, drilling engineering, mineral processing, rock mechanics testing, etc., and pave the way for the more effective use of these techniques for monitoring, measurement, and detection. In general, finding a suitable signal processing method that is appropriate for the intended purpose is very vital. Choosing the correct technique leads to prediction, monitoring or the correct diagnosis. The use of various $\mathrm{AE}$ techniques by installing specific sensors on equipment or during various processes, along with equipment for recording and sending data, reduces the presence of or different expensive equipment during the process. Data generated by various sensors can be recorded online, remotely or locally, and then processed and analysed for information extraction. Using this method, many of the costs in the project are reduced and the need to perform various stages of many tests, such as the determination of rock properties, will be eliminated. In many cases, such as the monitoring of equipment and mining machinery which may be a hazardous operation, the use of signal recording equipment increases the safety of operations. This will reduce the risk of safety in mining projects.

\section{References}

Aggelis, D. G., Shiotani, T., Momoki, S. and Hirama, A. (2009): Acoustic emission and ultrasound for damage characterization of concrete elements. ACI Materials Journal, 106, 6, 509.

Aldrich, D. (2000): Acoustic estimation of the particle size distributions of sulphide ores in a laboratory ball mill. Journal of the Southern African Institute of Mining Metallurgy, 100, 4, 243-248.

Ali, S. M., Hui, K., Hee, L. and Leong, M. S. (2018): Automated valve fault detection based on acoustic emission parameters and support vector machine. Alexandria engineering journal, 57, 1, 491-498.

Bastari, A., Cristalli, C., Morlacchi, R. and Pomponi, E. (2011): Acoustic emissions for particle sizing of powders through signal processing techniques. Mechanical Systems and Signal Processing, 25, 3, 901-916.

Beheshtizadeh, N. and Mostafapour, A. (2017): Processing of acoustic signals via wavelet \& Choi-Williams analysis in three-point bending load of carbon/epoxy and glass/epoxy composites. Ultrasonics, 79, 1-8.
Boness, R. and McBride, S. (1991): Adhesive and abrasive wear studies using acoustic emission techniques. Wear, 149, 1-2, 41-53.

Buj-Corral, I., Álvarez-Flórez, J. and Domínguez-Fernández, A. (2018): Acoustic emission analysis for the detection of appropriate cutting operations in honing processes. Mechanical Systems Signal Processing, 99, 873-885.

Byerlee, J. (1978): A review of rock mechanics studies in the United States pertinent to earthquake prediction. Rock Friction and Earthquake Prediction, 586-602.

Caesarendra, W., Kosasih, B., Tieu, A. K., Zhu, H., Moodie, C. A. and Zhu, Q. (2016): Acoustic emission-based condition monitoring methods: Review and application for low speed slew bearing. Mechanical Systems Signal Processing, 72, 134-159.

Du, F., Wang, K., Wang, G., Jiang, Y., Xin, C. and Zhang, X. (2018): Investigation on acoustic emission characteristics during deformation and failure of gas-bearing coal-rock combined bodies. Journal of Loss Prevention in the Process Industries.

Feng, H. and Yi, W. (2017): Propagation characteristics of acoustic emission wave in reinforced concrete. Results in physics, 7, 3815-3819.

Filipussi, D. A., Guzmán, C. A., Xargay, H. D., Hucailuk, C. and Torres, D. N. (2015): Study of acoustic emission in a compression test of andesite rock. Procedia Materials Science, 9, 292-297.

Flegner, P., Kačur, J., Durdán, M., Leššo, I. and Laciak, M. (2014): Measurement and processing of vibro-acoustic signal from the process of rock disintegration by rotary drilling. Measurement, 56, 178-193.

Futó, J. and ivaničová, L. (2003): Optimization of rock disintegration using the acoustic signal. Paper presented at the Proceedings of International Carpathian Control Conference.

Futó, J., Kostúr, K, and Kačur, J. (2005): Control and optimisation of rock disintegration based on acoustic background of drilling machine. Annals of the University of Craiova, 1 , 40-42.

Goyal, D. and Pabla, B. (2016): The vibration monitoring methods and signal processing techniques for structural health monitoring: A review. Archives of Computational Methods in Engineering, 23, 4, 585-594.

Gradl, C., Eustes, A. W. and Thonhauser, G. (2012): An analysis of noise characteristics of drill bits. Journal of energy resources technology, 134, 1, 013103.

Hampton, J., Gutierrez, M., Matzar, L., Hu, D. and Frash, L. (2018): Acoustic emission characterization of microcracking in laboratory-scale hydraulic fracturing tests, 1674-7755.

Hardy, H. R. (1972): Application of acoustic emission techniques to rock mechanics research. In Acoustic Emission: ASTM International.

Hatherly, P. (2002): Rock strength assessment from geophysical logging.

Hopwood, T. and McGogney, C. (1987): Acoustic emission applications in civil engineering. Nondestructive testing handbook, 5, 325-345. 
Jain, M. K., Schmidt, S. and Grimes, C. A. (2001): Magnetoacoustic sensors for measurement of liquid temperature, viscosity and density. Applied Acoustics, 62, 8, 1001-1011.

Jung, S., Prisbrey, K. and Wu, G. (1994): Prediction of rock hardness and drillability using acoustic emission signatures during indentation. International Journalof rock mechanics, 31, 5 .

Karakurt, I., Aydin, G. and Aydiner, K. (2013): Predictive modelling of noise level generated during sawing of rocks by circular diamond sawblades. Sadhana, 38, 3, 491-511.

Karakus, M. and Perez, S. (2014): Acoustic emission analysis for rock-bit interactions in impregnated diamond core drilling. International Journal of Rock Mechanics Mining Sciences, 68, 36-43.

Kawamura, Y., Jang, H. D., Hettiarachchi, D., Takarada, Y., Okawa, H. and Shibuya, T. (2017): A Case Study of Assessing Button Bits Failure through Wavelet Transform Using Rock Drilling Induced Noise Signals. Journal of Powder Metallurgy Mining, 6, 1, 1-6.

Kawasaki, S., Tanimoto, C., Koizumi, K. and Ishikawa, M. (2002): An attempt to estimate mechanical properties of rocks using the Equotip hardness tester. Journal of the Japan Society of Engineering Geology, 43, 4, 244-248.

Khoshouei, M., Bagherpour, R., Ghodrati, B. and Hosseinie, H. (2018): A Roadmap for Lean Maintenance of Mining Machinery. International Conference Mine of the Future, Available from: http://urn.kb.se/resolve?urn=urn:nbn:se:lt u:diva-71629.

Knill, J., Franklin, J. and Malone, A. (1968): A study of acoustic emission from stressed rock. Paper presented at the International Journal of Rock Mechanics and Mining Sciences \& Geomechanics Abstracts.

Kong, X., Wang, E., Hu, S., Li, Z., Liu, X., Fang, B. and Zhan, T. (2015): Critical slowing down on acoustic emission characteristics of coal containing methane. Journal of Natural Gas Science Engineering, 24, 156-165.

Kostur, K. and Futo, J. (2007): Optimization of rock disintegration based on acoustic background of drilling machine. Mechanics/AGH University of Science Technology, 26, 1, $1-7$.

Krúpa, V., Krul'áková, M., Lazarová, E., Labaš, M., Feriančiková, K. and Ivaničová, L. (2018): Measurement, modeling and prediction of penetration depth in rotary drilling of rocks. Measurement, 117, 165-175.

Kumar, B. R., Vardhan, H. and Govindaraj, M. (2010): Estimating rock properties using sound level during drilling: field investigation. International Journal of Mining and Mineral Engineering, 2, 3, 169-184.

Kumar, B. R., Vardhan, H. and Govindaraj, M. (2011a): Prediction of uniaxial compressive strength, tensile strength and porosity of sedimentary rocks using sound level produced during rotary drilling. Rock mechanics\& rock engineering, 44, 5, 613-620.

Kumar, B. R., Vardhan, H. and Govindaraj, M. (2011b): Sound level produced during rock drilling vis-à-vis rock properties. Engineering geology, 123, 4, 333-337.

Kumar, B. R., Vardhan, H., Govindaraj, M. and Saraswathi, S. P. (2013): Artificial neural network model for prediction of rock properties from sound level produced during drilling. Geomechanics Geoengineering, 8, 1, 53-61.

Kumar, B. R., Vardhan, H., Govindaraj, M. and Vijay, G. (2013): Regression analysis and ANN models to predict rock properties from sound levels produced during drilling. International Journal of Rock Mechanics Mining Sciences, 58, 61-72.

Lavrov, A., Wevers, M. and Vervoort, A. (2002): Acoustic emission during monotonic and cyclic deformation of a brittle limestone. Journal of Acoustic Emission, 20, 292.

Leššo, I., Flegner, P., Pandula, B. and Horovčák, P. (2007): New principles of process control in geotechnics by acoustic methods. Metalurgija, 46, 3, 165-168.

Li, J., Huang, Y., Chen, Z., Li, M., Qiao, M. and Kizil, M. (2018): Particle-Crushing Characteristics and AcousticEmission Patterns of Crushing Gangue Backfilling Material under Cyclic Loading. Minerals, 8, 6, 244.

Liew, K. and Wang, Q. (1998): Application of wavelet theory for crack identification in structures. Journal of engineering mechanics, 124, 2, 152-157.

Liptai, R., Harris, D. and Tatro, C. (1972): An introduction to acoustic emission. In Acoustic Emission: ASTM International.

Marceau, J. and Moji, Y. (1973): Application of fracture mechanics testing to process control for adhesive bonding. Document D6-41145, Boeing Commercial Airplane Company.

Marinescu, I. and Axinte, D. (2009): A time-frequency acoustic emission-based monitoring technique to identify workpiece surface malfunctions in milling with multiple teeth cutting simultaneously. International Journal of Machine Tools Manufacture, 49, 1, 53-65.

McNally, G. (1990): The prediction of geotechnical rock properties from sonic and neutron logs. Exploration Geophysics, 21, 2, 65-71.

Miklusova, V., Usalova, L., Ivanicova, L. and Krepelka, F. (2006): Acoustic signal-new feature in monitoring of rock disintegration process. Contributions to geophysics geodesy, 36, 125-133.

Mohanty, S., Gupta, K. K. and Raju, K. S. (2015): Vibration feature extraction and analysis of industrial ball mill using MEMS accelerometer sensor and synchronized data analysis technique. Procedia Computer Science, 58, 217-224.

Nair, A. and Cai, C. (2010): Acoustic emission monitoring of bridges: Review and case studies. Engineering structures, 32, 6, 1704-1714.

Obert, L. and Duvall, W. (1941): Use of subaudible noises for prediction of rockbursts II. report of investigation. S Bureau of Mines, Denve.

Parsian, A., Magnevall, M., Beno, T. and Eynian, M. (2017):Sound Analysis in Drilling, Frequency and Time Domains. Procedia CIRP, 58, 411-415.

Pedrayes, F., Norniella, J. G., Melero, M. G., MenendezAguado, J. M. and del Coz-Diaz, J. J. (2018): Frequency domain characterization of torque in tumbling ball mills using DEM modelling: Application to filling level monitoring. Powder Technology, 323, 433-444. 
Qin, M., Wang, K., Pan, K., Sun, T. and Liu, Z. (2018): Analysis of signal characteristics from rock drilling based on vibration and acoustic sensor approaches. Applied Acoustics, 140, 275-282.

Raffenetti, R. C., Hsu, K. and Shavitt, I. (1977): Selection of terms for a CI wavefunction to preserve potential surface features. Theoretica chimica acta, 45, 1, 33-44.

Rivero, A. d., de Lacalle, L. L. and Penalva, M. L. (2008): Tool wear detection in dry high-speed milling based upon the analysis of machine internal signals. Mechatronics, 18, 10, 627-633.

Schön, J. H. (2015): Physical properties of rocks: Fundamentals and principles of petrophysics (Vol. 65): Elsevier.

Scruby, C. (1987): An introduction to acoustic emission. Journal of Physics E: Scientific Instruments, 20, 8, 946.

Shaffer, D., Ragai, I., Danesh-Yazdi, A. and Loker, D. (2018): Investigation of the feasibility of using microphone arrays in monitoring machining conditions. Manufacturing Letters, $15,132-134$.

Shreedharan, S., Hegde, C., Sharma, S. and Vardhan, H. (2014): Acoustic fingerprinting for rock identification during drilling. International Journal of Mining Mineral Engineering, 5, 2, 89-105.

Spencer, S., Bruniges, R., Sharp, V., Catanzano, V., Roberts, G., Bruckard, W. and Davey, K. (2010): Acoustic emission monitoring of froth flotation. Paper presented at the Proceedings of the XXV International Mineral Processing Congress. AUSIMM, Melbourne.

Szlavin, J. (1974): Relationships between some physical properties of rock determined by laboratory tests. Paper presented at the International Journal of Rock Mechanics and Mining Sciences \& Geomechanics Abstracts.

Utley, W. A. (1980): Noise from opencast coal mining sites. Applied Acoustics, 13, 2, 85-102.

Vardhan, H., Adhikari, G. and Raj, M. G. (2009): Estimating rock properties using sound levels produced during drilling. International Journal of Rock Mechanics\& Mining Sciences, 46, 3, 604-612.

Vardhan, H. and Murthy, C. S. (2007): An experimental investigation of jack hammer drill noise with special emphasis on drilling in rocks of different compressive strengths. Noise control engineering journal, 55, 3, 282-293.

Verwaal, W. and Mulder, A. (1993): Estimating rock strength with the Equotip hardness tester. Paper presented at the International Journal of Rock Mechanics and Mining Sciences and Geomechanics Abstracts.
Voznesenskii, A. S., Krasilov, M. N., Kutkin, Y. O., Tavostin, M. N. and Osipov, Y. V. (2017): Features of interrelations between acoustic quality factor and strength of rock salt during fatigue cyclic loadings. International Journal of Fatigue, 97, 70-78.

Wang, K., Liu, G., Wu, J., Liu, Z., Yi, L., Zhang, J. and Du, J. (2017): Acoustic sensor approaches for sand detection in sand-water two-phase flows. Powder Technology, 320, 739-747.

Ward, B. J. (1998): German Creek Mines Rock strength from velocity logs. Unpublished report for Capricorn Coal Management Pty Ltd.

Williams, E. and Hagan, P. (2006): Observations on the variation in acoustic emissions with changes in rock cutting conditions. Paper presented at the Coal Operators' Conference.

Xiao, Y., Hurich, C., Molgaard, J. and Butt, S. D. (2018): Investigation of active vibration drilling using acoustic emission and cutting size analysis. Journal of Rock Mechanics Geotechnical Engineering, 10, 2, 390-401.

Yamada, I., Masuda, K. and Mizutani, H. (1989): Electromagnetic and acoustic emission associated with rock fracture. Physics of the Earth Planetary Interiors, 57, 1-2, 157-168.

Yari, M., and Bagherpour, R. (2018): Inovativni model za istraživanje i opisivanje obrađenih taložnih stijena analizom zvučnih (akustičnih) frekvencija dobivenih tijekom bušenja. Rudarsko-geološko-naftni zbornik, 33, 2, 25-25.

Yari, M. and Bagherpour, R. (2018): Implementing Acoustic Frequency Analysis for Development the Novel Model of Determining Geomechanical Features of Igneous Rocks Using Rotary Drilling Device. Geotechnical Geological Engineering, 36, 3, 1805-1816.

Yari, M., Bagherpour, R. and Khoshouei, M. (2017): Developing a novel model for predicting geomechanical features of carbonate rocks based on acoustic frequency processing during drilling. Bulletin of Engineering Geology the Environment, 1-13.

Zborovjan, M. (2002): Identification of Minerals from Sound During Drilling. Semestral Project. TU-Kosice.

Zborovjan, M., Lesso, I. and Dorcak, L. (2003): Acoustic identification of rocks during drilling process. Journal of Acta Montanistica Slovaca, 8, 4, 91-93.

Zhu, X., Xu, Q., Zhao, Z. and Li, T. (2016): Low frequency acoustic signals associated with rock falls, thunderstorms, and wind turbulences in field environment. Applied Acoustics, 112, 131-139. 


\section{SAŽETAK}

\section{Pregled primjene odašiljanja zvučnih valova u rudarstvu i znanostima o Zemlji}

Jedan od najčešće primjenjivanih alata u rudarstvu i znanostima o Zemlji jesu visokofrekvencijski, elastični, zvučni valovi. Oni mogu biti koristan alat za predviđanje i mjerenje, praćenje i prepoznavanje okoliša te su specifični, mjerljivi, dostupni, pouzdani i utemeljeni na vremenu (skr. SMDPV, engl. SMART). Emitiranje zvuka može biti dijelom inženjerskih operacija poput otkapanja, procjene volumena ili istraživanja. Stoga su oni primijenjeni u opažanju, praćenju i mjerenju inženjerskih pojava. Razvojem obradbe zvučnih signala te rastućom potrebom za točnim, brzim i ekonomski povoljnim predviđanjem, praćenjem i mjerenjem, te metode postaju zamjena postojećim metodama druge vrste u različitim vrstama projekata. Ovdje su prikazane uporabe zvučnih valova u različitim znanostima o Zemlji, poput rudarstva, bušenja, geologije, naftnoga inženjerstva i sličnim granama. Primjena zvučnih valova podijeljena je u tri skupine: predviđanje i procjena, praćenje i procjena svojstava te opažanje. Njihovo korištenje u usporedbi s laboratorijskim i bušaćim tehnikama vrlo je brzo i točno, a uz odgovarajuću tehničku opremu signali se mogu primijeniti i obraditi na mjestima udaljenim od onih gdje se mjerenje izvodi. Na kraju je opisana primjena zvučnih metoda u procjeni različitih projekata kao alata za donošenja odluka.

\section{Ključne riječi:}

zvučni val, obradba signala, znanosti o Zemlji, rudarsko inženjerstvo, ocjena specifičnosti, mjerljivosti, dostupnosti, pouzdanosti i utemeljenosti na vremenu (engl. SMART)

\section{Authors contribution}

Mehrbod Khoshouei, MS.c. student and Raheb Bagherpour, Associate Professor of Isfahan University of Technology, shared contributions in collecting different studies as well as defined and compared AE applications in mining and earth sciences. 